\title{
The Path of Financial System Supports Small and Medium-sized Technology-based Enterprises
}

\author{
Yifan Shi \\ Beijing Jiaotong University, BJTU \\ Beijing, China
}

\begin{abstract}
The article mainly studies the path of the financial system to support the development of small and medium-sized enterprises in science and technology. The main point is that the financial system can influence the development of small and medium-sized enterprises by means of financing environment and financing channels. The financing environment of small and medium-sized enterprises in China and the present situation of the financing channel are analyzed, pointing out that some problems are hindering the development of the science and technology of small and medium-sized enterprises. The effects are not obvious although the financing environment and financing channels of some small and medium-sized enterprises in China have been developed and many measures have just been implemented. If we want to solve the problems about the financing for science and technology of the small and medium-sized enterprises, we still need to accelerate the process of financial innovation.
\end{abstract}

Keywords-financial system; science and technology small and medium-sized enterprises; financing environment; financing channels

\section{INTRODUCTION}

Small and medium-sized enterprises play an important role in the process of economic growth in China. According to statistics, $70 \%$ of urban residents and $80 \%$ of migrant workers are employed in small and medium-sized enterprises. And small and medium-sized technology-based enterprises are the most innovative, dynamic and fastest-growing one. Although the central and local governments have taken a series of measures to encourage small and medium-sized enterprises, they did not make any difference. There are still serious financing constraints in the development of small and medium-sized technology-based enterprises.

\section{LITERATURE REVIEW}

The previous studies on financial support for science and technology enterprises mainly focused on the following aspects: from the perspective of direct or indirect financing to explore its support for science and technology enterprises; A lot of papers analyze the status and problems; Some use empirical analysis to explore the support of the financial system for science and technology enterprises. The status of the financial markets in which an enterprise is located affect the choice of the type of technological innovation (Gilles Saint - Pual, 1992), and the impact of the financial system on the technological innovation capability of enterprises can be achieved by assessing the entrepreneur's ability (King and Levine, 1993). There is a positive correlation between the share of corporate loans and the intensity of R\&D (Helmet and Karsten, 2015). The impact of finance on the development of enterprises is more and more obvious and financial support is one of the key factors to promote independent innovation of small and medium-sized technology-based enterprises. In the long run, the financial system of different regions will play a supportive role for the independent innovation of small and medium-sized enterprises. At present, the indirect financial is dominant in financial system in China, therefore the credit support must play an significant role in science and technology enterprises. And with the development of the Internet financial, people change the way of thinking and behavior, Internet financial can provide a new financing channel for small and mediumsized enterprises.

\section{PATH ANALYSIS}

Financial refers to the financial intermediation, the main function of the financial system is to allocate funds reasonably and efficiently. The macro-financial system of small and mid-sized enterprises can affect the financing restraint received by small and medium-sized enterprises. The financial system to support small and medium-sized technology-based SMEs mainly by changing the corporate financing channels and financing environment, thus affecting the ability of corporate finance and financing efficiency, and ultimately promote the development of enterprises.

\section{A. Financing Environment}

The financing environment of small and medium-sized technology-based enterprises is a collection of factors that affect the financing activities of small and micro enterprises under certain system mechanisms. The financing environment has a decisive influence on the development of small and micro enterprises' financing activities: on the one hand, it provides opportunities and conditions for small and micro enterprise financing, on the other hand, it plays negative role in the small and micro enterprise financing or plays restriction, intervention, and even stress role. The financing environment includes internal financing environment and external financing environment. The internal financing environment mainly refers to the 
enterprise's own factors that affect corporate finance, such as the financial status of enterprises, the development status of enterprises and the credit status of enterprises. The external financing environment mainly includes some policies to promote or suppress financing and the overall economic development. The financial system can influence the financing of enterprises by changing the financing environment of small and medium-sized enterprises, and improving the financial environment. Enterprises get funding and put into research and transformation of science and technology, the product eventually able to produce, sell, after that businesses can grow.

\section{B. Financing Channels}

The financial system can promote enterprise growth by broadening the corporate financing channel. Financing channels also include internal financing channels and external financing channels. The internal financing channel is the enterprise's own capital, which is generally the preferred method of financing for enterprises. External financing channels include direct financing and indirect financing. The emergence of new financing channels is conducive to the financing of enterprises and the development of small and medium-sized enterprises. For example: the emergence of the Internet financial makes the financing difficulty of science and technology enterprises to the Internet looking for money, for money, make the plan doesn't die, increasing the success rate of the science and technology enterprises.

\section{THE PROBLEMS IN FINANCING}

\section{A. Financing Environment Problems}

From the perspective of financing environment, the financing environment of small and medium-sized enterprises is not optimistic, which is largely determined by the nature of technology-based enterprises.

- First of all, compared with large enterprises, small and medium-sized technology-based enterprises are in their infancy. It is small and has a special character of "light asset", which is special for science and technology enterprises. Moreover small and mediumsized technology-based enterprises have little market competitiveness, even cannot develop products. But they need a large number of long-term financing. Most of small and medium-sized technology-based enterprises are managed badly and has poor ability to pay off and financing. The enterprise development prospect is uncertain and the risk is very high. There will be great uncertainty and a long-term payback for investors who put investment to small and mediumsized technology-based enterprises, although there may be high returns.

- Second, some deficiency (such as: poor awareness of financial information disclosure, lacking of transparency and necessary supervision, inadequate management system) makes it difficult for those enterprises to get the loan. Because they cannot meet the bank loan terms of commercial banks. Bank and investors cannot assess the credit level of small and medium-sized enterprises exactly. In addition, due to its weaker management, big market volatility, enterprise location is not fixed, employee changes frequently, which will badly affect the financing of enterprises. Identify applicable sponsor/s here. If no sponsors, delete this text box (sponsors).

- Although the government's provides some policies to support technology-based small and medium-sized enterprises (such as: government leading fund, risk compensation fund, business incubator projects, etc.). However, compared with the big market environment, it is not strong enough to support the development of small and mid-sized enterprise.

\section{B. Financing Channels Problems}

- At present, China's financial market is dominated by indirect financing, while indirect financing channel is the bank credit. Commercial bank's credit appraisal system and credit management system mainly aims to large enterprises. The assets structure of small and middle-sized enterprises is very difficult to adapt to the requirement of commercial banks. The robustness of financial institutions such as commercial banks requires that their credit funds released to customs meet the demand of safety, liquidity and efficiency. Commercial banks are asked to strictly control the proportion of non-performing loans, so they have a strict review mechanism for lending programs and strict requirements for guarantees and mortgages. It is difficult to get loans from banks to get loans (Carpenter and Petersen, 2002) for small and middlesized technology-based enterprises which are mostly short of fixed assets and profitless. The small and medium-sized technology-based enterprises are in their hatching period or the initial period, the risk is high, the income is uncertain, which are discrepancy with commercial operation principle. Insufficiency of information is a key factor which can affect the financing of small and middle-sized technologybased enterprises (Berger and Udell, 1998). Mortgages are indispensable for an enterprise who wants to get commercial bank loans, but small and middle-sized enterprises generally unable to provide some mortgages. The loan amount and loan interest cannot be paid for banks, once the enterprises have management problems. All of those factors make it impossible for a large number of small and mediumsized enterprises to get loans from commercial banks. Indeed, commercial is the outcome of industrialization in China.

- At present, angel investors, venture capital, private capital investment, the Internet, National Equities Exchange and Quotations, Growth Enterprise Market and main board market are main direct financing channels in China. Angel investments and venture capital investments invest in companies in the time when it has just been started meanwhile hold shares, 
and exit when companies are mature or fail. The sources and sizes of venture capital are limited, which are mainly from venture capital firms and only few companies could get investment. And many companies eventually fail to meet the requirements of Initial Public Offerings, making it difficult to exit for venture capital and reduce the investment enthusiasm. Although our country has introduced the Internet, National Equities Exchange and Quotations, and Growth Enterprise Market, they require a high threshold. The one who can achieve those conditions are companies that already have a certain size and market recognition. So the financing channel is not applicable for small and middle-sized enterprises. While the new three board market has experienced rapid growth, the listed companies from 200 in 2012 rose to 10163 in 2016, which increased nearly 50 times. But the science and technology enterprises (information transmission, software and information technology services, scientific research and technical services) accounted for $26.4 \%$, about more than 2600 . Contrast to the amount of small and medium-sized science and technology enterprises, the quantity of technology enterprises is little.

- Without proper supervision and management, the development of Internet finance is still immature in China. Internet refinancing is supposed to be a proper way for small and medium-sized technology-based enterprises to financing. However the general financing quota is small and the financing period is short. For small and mid-sized enterprise in startup period, the financing volume through Internet finance can provide is limited. And the online lending platforms have been exposed to problems such as running, fraud, which lead to people lack of trust in Internet financing. In Shenzhen, for example, in April 2017, the amount of the financing platforms that are still in normal operation is badly decreased. Furthermore the amount of closed platforms has reached 10. Meanwhile, in April, the volume of Internet loans in Shenzhen was 38355 million yuan, 7 percent down from the previous month.

\section{THE FINANCIAL SYSTEM INNOVATION}

\section{A. Financing Environment Innovation}

- The collaboration between the industry, schools and research institutions can make good use of their respective advantages, formed advanced systems with a strong research, development, production integration and reflects the comprehensive advantage in the operation process. "Production" refers to enterprises, "learning" means institutions of higher learning, "research" means scientific institutions. The essential characteristic of technology innovation is the combination of technology and economy, main components of national innovation system is: enterprises and institutions of higher learning, scientific research structure, government departments, agencies, etc. Among them, the enterprises are the main body of technological innovation, the core of the system. And the institutions of higher learning have obvious advantages in scientific research institutions, such as scientific research, achievement, education, and information. Therefore, the innovation mode of the combination of the above three aspects promote the development of science and technology and economic increasingly, and further promote the innovative development of science and technology enterprises.

- The government strongly supports small and medium-sized technology-based enterprises and has introduced a series of policies to solve its financing difficulties. First, the government guided funds are set up to invest in venture capital institutions to channel funds to start-ups. And many local governments have created compensation platforms, which aims to lend to small and middle-sized enterprises. When the bank loan money to those companies, the government will allocate funds to the bank to compensate the loan risk, and alleviate the problems of small and medium-sized enterprise financing. Risk compensation fund for small and middle-sized enterprise encourages financial institutions to increase its credit supply, increase the enthusiasm of financial institutions to invest in science and technology enterprises.

\section{B. The Financing Channels Innovation}

The bank has started to establish science and technology banks which will specially lend to technology companies. Relax risk tolerance index of science and technology bank, changing the way and performance, developing is suitable products and services for small and mid-sized enterprise, being personalized and diversified. In 2012, Shanghai Pudong Development Bank Silicon Valley joint venture was finally officially listed in Shanghai which is the first real technology bank in China. The optimization of direct financing channel financial system focuses on $\mathrm{P} 2 \mathrm{P}$ lending and crowd-funding in Internet finance. Internet finance has the functions of lowering the information asymmetry and reducing the cost of financing. The innovation of the Internet financial model provides a new channel of financing for small and medium enterprises, improving the efficiency of financing, to some extent, solving the problem of asymmetric information.

\section{CONCLUSION}

The development of small and medium-sized enterprises in science and technology must be supported by the financial system, and the financial system should provide sufficient funds to products and technologies research and development. This paper mainly studies the paths of the financial system to support the development of small and medium-sized enterprises. The main conclusions of this article are:

- The system of financial system can affect the development of small and medium-sized technology- 
based enterprises through both financing environment and financing channels two aspects. The financing environment of small and medium-sized technologybased enterprises refers to the collection of various factors that affect the financing activities of enterprises under specific institutional mechanisms. The financial system can broaden the financing channels of corporate, so that businesses can get money more convenient.

- The financing environment for small and mediumsized enterprises in China is very complex; enterprises must face some problems, such as poor credit and so on. The financing channel of small and medium-sized enterprises in science and technology has high financing cost and asymmetric information.

- Although some financial innovations have been made in our country to promote the development of science and technology enterprises, the effects have to be further verified. Both direct financing and indirect finance should accelerate the innovation in the financial system, to promote the development of small and medium-sized enterprises.

\section{REFERENCES}

[1] Saint-paul G. Technological choice, financial markets and economic development[J]. European Economic Review, 1992, 36(4): 763-781.

[2] King R G, Levine R. Finance, entrepreneurship and growth [J]. Journal of Monetary Economics, 1993, 32(3): 513-542.

[3] Helmet Fryges, Karsten Kohn. The Interdependence of R\&D Activity and Debt Financing of Young Firms [J]. Journal of Small Business Management, 2015, 53(Supplement):251-277.

[4] Carpenter R E, Petersen BC. Capital market imperfections, high tech investment, and new equity financing $[\mathrm{J}]$. The Economic Journal, 2002, 112(477): F54 - F72.

[5] Berger A N, Udell G F. The economics of small business finance: The roles of private equity and debt markets in the financial growth cycle $[\mathrm{C}] / /$ Conference on the Economics of Small Business Finance. 1998:613-673.

[6] Donner S D, Kandlikar M, Zerriffi H. Environment and development. Preparing to manage climate change financing.[J]. Science, 2011, 334(6058):908-9.

[7] Valentina H, Dennis N. Financing Constraints and Access to Credit in a Postcrisis Environment: Evidence from New Farmers in Alabama[J]. Journal of Agricultural \& Applied Economics, 2012, 44(4):607-621.

[8] Jing B, Chen X, Cai G. Equilibrium Financing in a Distribution Channel with Capital Constraint[J]. Production \& Operations Management, 2012, 21(6):1090-1101. 